\title{
南部フォッサマグナ，甲府盆地の低角逆断層の 地下構造とネットスリップ
}

\author{
東京大学理学部地理学教室* 隈 元 崇・池田安隆
}

\section{Fault Geometry and Net Slip of Low Angle Thrust Faults in the Kofu Basin, Central Japan}

\author{
Takashi Kumamoтo and Yasutaka Ikeda \\ Department of Geography, University of Tokyo, Hongo 7-3-1, \\ Bunkyo-ku, Tokyo, 113
}

(Received May 6, 1993; Accepted August 2, 1993)

\begin{abstract}
The Kofu basin is situated in the south Fassa Magna, and is bordered on the west and south by active thrust faults. Previous studies have suggested that these faults are low angle thrust, from qualitative evidence. The activity of these faults has been evaluated in terms only of vertical slip rates, in spite of the fact that a low angle thrust fault has significant component of horizontal shortening. We attempted to determine the rates of net slip on these faults using gravity and geomorphological data. First, the geometry of the faults to $2-3 \mathrm{~km}$ depths was determined by using closely spaced gravity values across the faults. In the Sone Hills along the south margin of the Kofu basin, the master boundary fault (presently inactive), which has thrust basement rocks northward over basin fill sediments, dips $10^{\circ}$ south. The frontal active fault at the northern margin of the hills dips $5^{\circ}$ south, and develops wholly within the basin fill sediments, indicating thrust-front migration. In the Ichinose Upland along the west margin of the basin, however, the boundary fault (dipping $18^{\circ}$ west) between basement rocks and basin fill sediments lies in front of the foothills, not at the topographic range front; the active fault at the range front is likely to be a secondary or subsidiary fault. Second, the rate of net slip on these faults was determined by elastic dislocation models, using geomorphologically observed surface deformation and the fault geometry that were deduced from gravity anomaly. The net slip rates were found to be $1.3 \mathrm{~mm} / \mathrm{yr}$ for the Sone Hills, and as high as 6.3$8.3 \mathrm{~mm} / \mathrm{yr}$ for the Ichinose Upland. These results indicate that the west margin of the Kofu basin is subjected to horizontal shortening in an $\mathrm{E}-\mathrm{W}$ direction at an extremely high rate, whereas the south margin of the basin is subjected to horizontal shortening in a NW-SE direction at a lower rate.
\end{abstract}

Key words: Thrust fault, Horizontal shortening, Net slip rate, Gravity anomaly, Dislocation model, Tectonic geomorphology.

\section{§1.はじめに}

フォッサマグナの西縁をなす広義の糸魚川-静岡構造 線は地質構造上の顕著な境界であるのみならず, 第四紀 の変位地形を形成する活断層の存在という点で現在のテ クトニクスを明らかとする上でも重要な地域である.

また最近では中村 (1983) や小林 (1983) の東北日本北 米プレート説以来, この地域のプレート収束境界の問題 に関する多くの議論がなされてきた［例えば松田

于113 東京都文京区本郷 7-3-1
(1989)，衣笠(1990)など]。活断層研究の立場からも， 変位様式, 活断層の活動度, 活動開始時期などプレート 境界の問題を検討するための有意義な情報が得られてい る. しかし, フォッサマグナ西縁の活断層の変位様式は, 北部では横ずれ成分が卓越するのに対し, 南部では逆断 層成分が卓越する，逆断層のネットスリップ算出は一般 に困難なことから, 真の平均変位速度に関して全体的な 比較をすることがこれまでできなかった．このため活断 層のセグメンテーションや応力場など残された課題も多 い. そこで本論ではフォッサマグナ西縁南部に位置する 


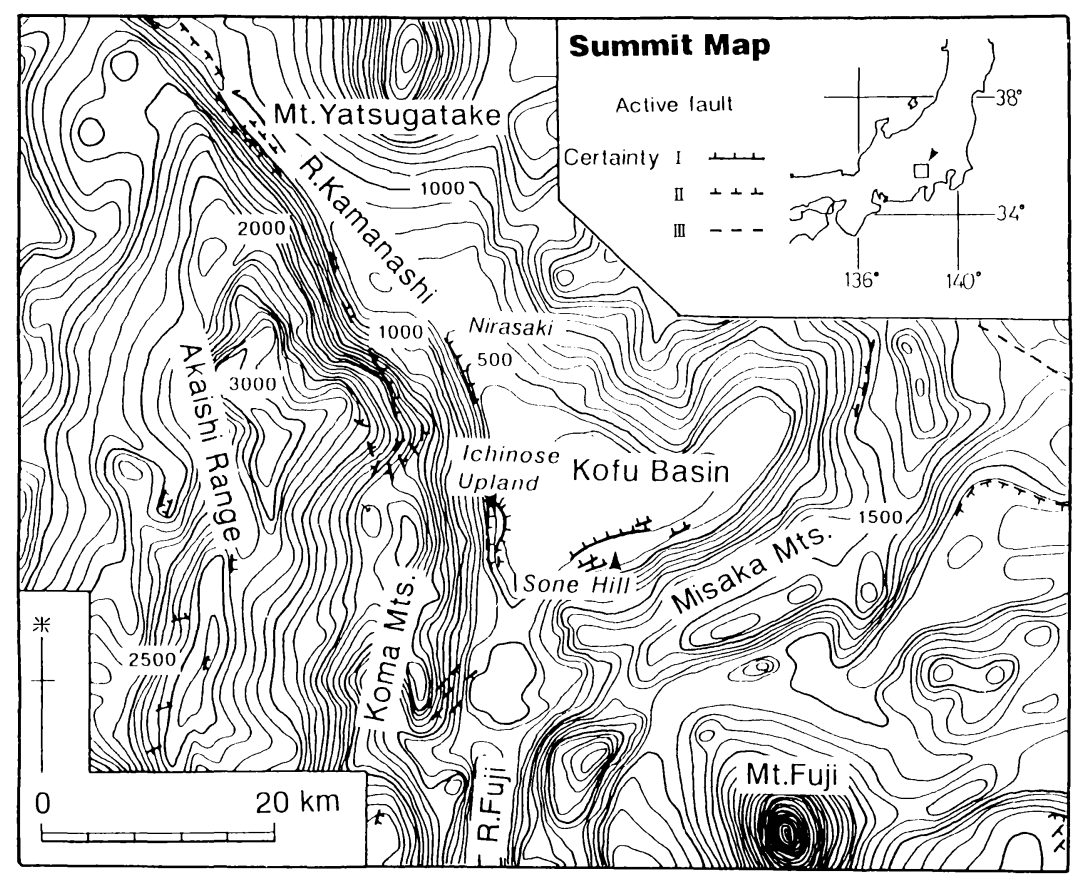

Fig. 1. Map showing generalized topography and the distribution of active faults in and around the Kofu basin. Active faults are after Research Group of Active Faults of Japan (1991). Contours are at 100 meter intervals. Symbols for active faults: solid lines with teeth, certainty I (definitely active); dashed lines with teeth, certainty II (probably active); dashed lines without teeth, certainty III (possibly active). Teeth indicate downthrown sides.

逆断層のネットスリップ速度を明らかとすることを試み た.

フォッサマグナ西縁の菲崎市円井には第四紀碟層を切 る衝上断層が存在することが古くから知られている［大 塚(1941)]。これより南では逆断層による变位地形が分 布するが，本論では特に変位地形の明瞭な甲府盆地内の 活断層をとりあげる，甲府盆地ではその南縁と西縁に活 断層による変位地形が認められる。しかしその走向は著 しく斜交しており，それを踏まえた甲府盆地のプレート 三重会合域説 [石橋 (1983)] などの議論に関しても活断 層の活動度を明らかとすることは重要な意味をもつと考 えられる。

甲府盆地の南縁の兽根丘陵および西縁の市之瀬台地の 地形 (Fig. 1) については田中 (1925) 以来多くの研究が ある.それらは大別すると, 丘陵・台地を傾動地塊とし その成因には台地や丘陵前縁の断層運動か関与している とする説 [花井 (1934), 澤 (1981)］と, 丘陵・台地の直 接の成因は断層運動による変位ではなく背後山地からの 重力性の滑落であるとした説 [中村 (1938), 崎田 (1961)，金子(1972)] とに大別できる.しかし，変形を 受けた扇状地面の存在 [澤 (1981)], 約 30 万年前に堆積 したと考えられる菲崎泥流堆積物の断層を挟んだ高度差
[海野 (1981)], 兽根丘陵前縁部での撓曲構造の存在 [平 川 (1982,1992)] などから丘陵之台地の形成にはそれぞ れ前縁部の低角逆断層運動が関わっていることが明らか となった.

これらの活断層の平均変位速度は, 垂直成分のみに関 して, 兽根丘陵で約 $0.5 \mathrm{~mm} / \mathrm{yr}$, 市之瀬台地で $1 \sim 1.4$ $\mathrm{mm} / \mathrm{yr}$ と見積られている [澤 (1981)]. しかし低角逆断 層では，見積りの困難な水平短縮成分が大きいと予想さ れるので, 従来のように垂直成分のみから活動度を評価 するには問題がある.

本論では逆断層のネットスリップ速度を明らかとする ために，まず断層を横切る測線に沿ったブーゲー重力異 常データの解析から浅部密度構造を推定し断層の傾斜角 を求めた. 次に断層モデルをもちいて, 先に得られた傾 斜角と観察される地表変形の両方を満たす逆断層のネッ トスリップ速度を計算した。

\section{§2. 甲府盆地内の活断層に関する地形的な特徵}

甲府盆地は南部フォッサマグナに位置する構造性の盆 地である. 甲府盆地の周囲は, 西に標高 $1500 \sim 3000 \mathrm{~m}$ の巨摩山地・赤石山脈, 南に標高 $1000 \sim 1500 \mathrm{~m}$ の御 坂山地，北部は関東山地が取り囲む．特に西緣之南緣の 


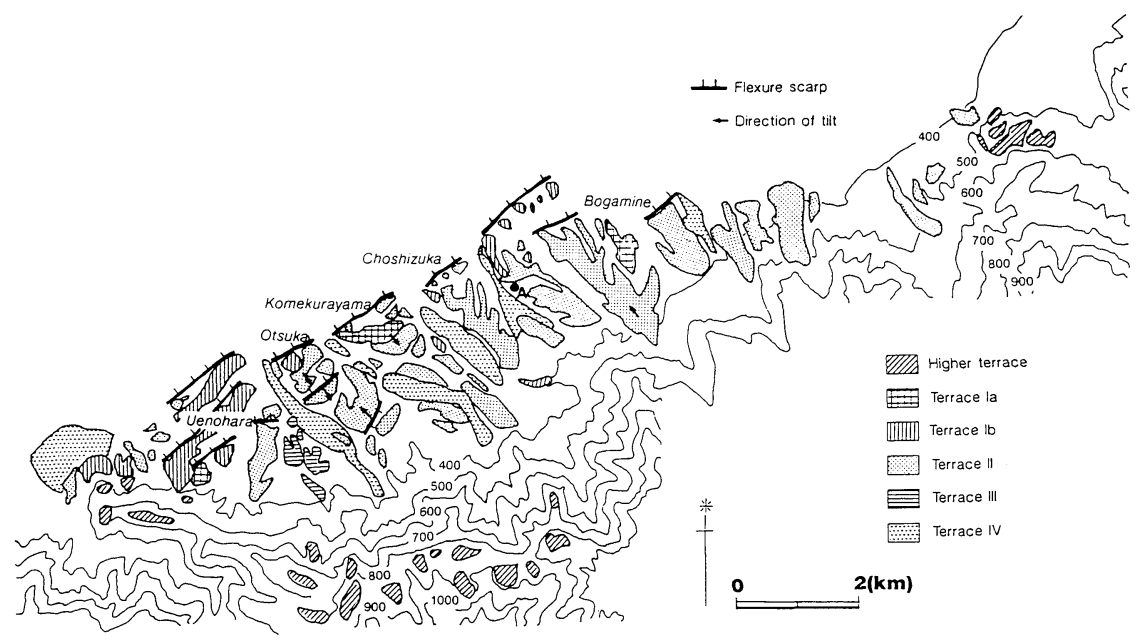

Fig. 2. Geomorphological map of the Sone Hills. Contours are at 100 meter intervals. Arrows indicate directions of tilt. The Saku silt bed, which is used as a reference horizon for surface deformation, is well exposed at locality A.

山地と盆地の境界は, Fig. 1 の接峰面図から読み取れる ように急峻な断層崖をなし，さらに新期の変動地形が顕 著である [例えば, 活断層研究会 (1991)].

本論では活断層の変位を反映して形成された盆地南縁 の曽根丘陵と西縁の市之瀬台地について, 後述する断層 モデルの適用に関連する地形の変形量を推定するための 資料を得るために，空中写真判読および現地調査を行っ た.

\section{1 曽根丘陵の地形と変動の特徵}

兽根丘陵は, 主として御坂山地から流れ出る河川に よって形成された合流扇状地面が，活断層による変位を 受けて形成された地形である.

丘陵内に分布する地層は，第四紀前期・中期の扇状地 碟層・湖沼堆積物や八ヶ岳起源の菲崎泥流堆積物を含む 曽根層群といわれる堆積物と, これを覆うより新しい扇 状地碟層からなる，兽根丘陵の第四紀層は，御坂山地の 御坂層群（中新世）之南傾斜の逆断層（以下では境界断 層と呼ぶ）で境される [日本の地質「中部地方 I」編集委 員会 (1988)]． 境界断層に沿っては第四紀後期の活動を 示す変位地形が認められない. 新期の変位地形は以下に 示すように丘陵北縁に発達する.

曾根丘陵の地形面は上位から I, II, III, IV 面に区分で きる (Fig. 2).

I 面は, 丘陵東端坊ヶ峰から丘陵北縁に沿って連続す る銚子塚，王塚，米倉山，上野原，あるいは丘陵南西の 平坦面など，標高 380〜400 m の地形面をさす。澤 (1981) はこのうち坊ヶ峰のみをボーリング資料でいう 下部絽層 [海野 (1981)] 相当の寺尾砂礫層からなる面と
し，残りを菲崎泥流堆積物からなる面とした。しかし平 川 (1992) に示された丘陵前縁の撓曲変形の内部構造か ら明らかなようにこれらの地形面は，曽根層群といわれ る砂礫層・火砕流堆積物・シルト層・泥流堆積物から成 る地層が，活断層による撓曲変形と地震間の河川による 侵食を受けて形成された侵食面と考えられる。 そこで本 論では，I面を兽根層群を切って発達する侵食面全体と 考え, 活断層による変位の積算や侵食の程度を反映した 標高の違いから相対的に高位の Ia 面と低位の Ib 面に再 区分した。兽根丘陵前縁では兽根層群の下位に基盤岩は 観察されない。

II 面は山麓から丘陵前縁の I 面の高まりの背後までの 間に北西に緩く傾斜して分布する面であり，その範囲は 丘陵内で最も広い.この面を構成するのは御坂山地から の扇状地碟層であり，ボーリング資料から得られた甲府 盆地床下の上部礫層 [海野 (1981)］に相当する．この地 層は下位の兽根層群とは著しい傾斜不整合で接する．碟 層の上位には層厚 $60 \sim 90 \mathrm{~cm}$ の風成の Pm-I 軽石層が のり, さらに上位に厚さ $1 \sim 3 \mathrm{~m}$ の褐色風化火山灰をの せる．これより II 面は Pm-I 軽石層の降下した約 8 万年 前には離水していたと考えられる。

III 面は丘陵西部にわずかに分布する標高 $280 ３ 50$ $\mathrm{m}$ の面で周囲の II 面より低く IV 面より高い. 澤 (1981) は比高数 $\mathrm{m}$ の崖でさらに 2 分している. 現地では構成 層およびローム層の有無を確認できるような露頭はみあ たらないので断定はできないが，II 面を切って形成され た河成の侵食段丘と考えられる.

IV 面は丘陵内を北西に流れる河川が上位の面を侵食 


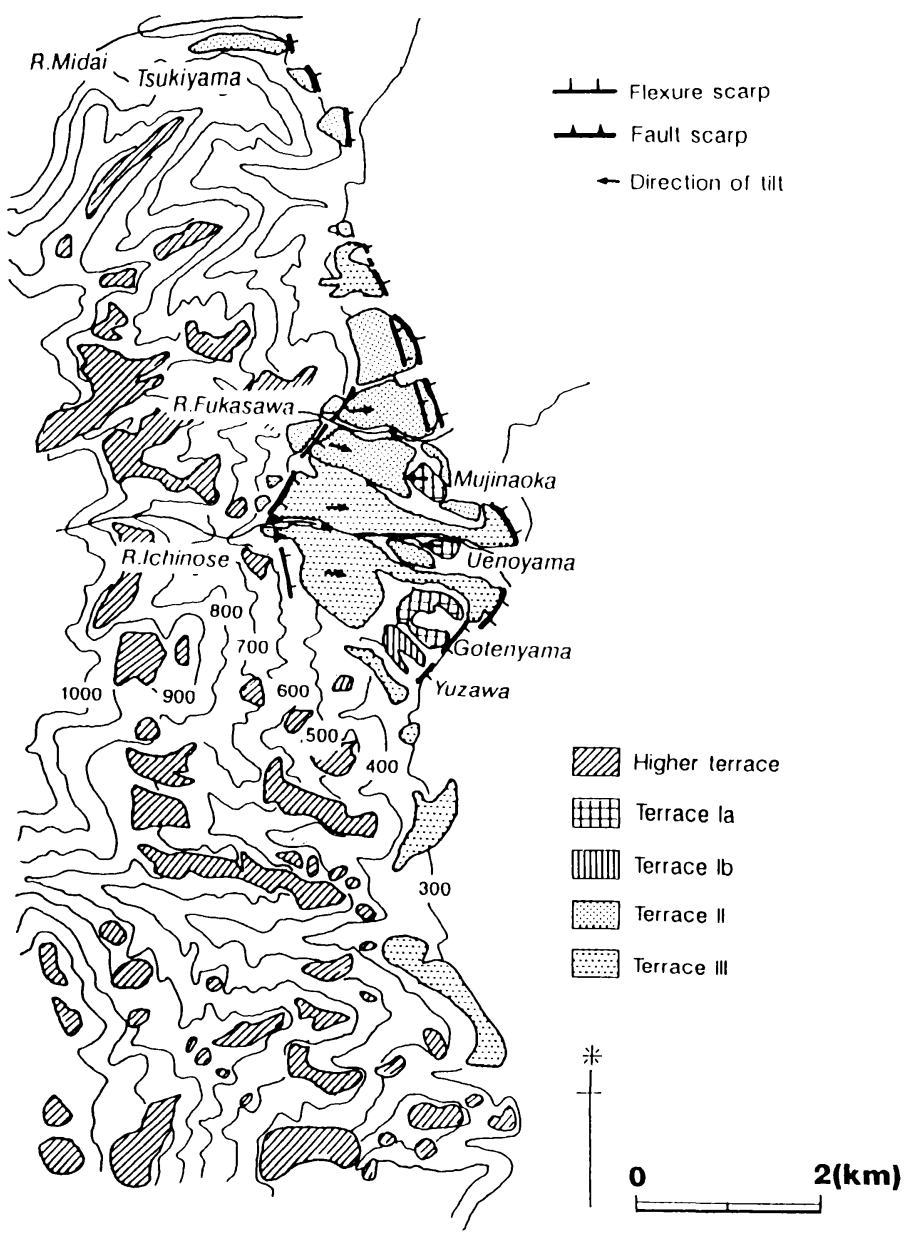

Fig. 3. Geomorphological map of the Ichinose Upland. Contours are at 100 meter intervals.

して形成した標高 280〜 400 m の段丘面である. IV 面 は火山灰に覆われないことからおおよそ 2 万年前以降 に形成されたと考えられる [甲府盆地第四紀研究グルー プ (1969)]. 丘陵内の現河川はこの面をさらに数 $\mathrm{m}$ 刻ん で北西に流下している.

曽根丘陵に見られる変位地形は，丘陵前縁に分布する I 面の撓曲変形と， その背後の扇状地面を形成する II 面 の山地側への逆傾斜を特徴とする. このような変形を連 続的に表現するために, 平川 $(1982,1992)$ が示したバル ジ内の変形構造, Fig. 2 の A 地点の露頭観察, および西 宮・石田 (1967) の電気探査の結果にもとづいて, 曽根 層群中の佐久シルト層の構造を明らかとした。佐久シル 卜層は下位の黑富士火砕流を整合に覆うシルト・砂から なる湖沼性堆積物であり, 堆積時はほぼ水平であったと 推定される，その年代は，佐久シルト層中に含まれる軽 石首が大町 Apm に同定されることから約 30〜35 万年 前と考えられている [Suzuki (1991)]．バルジ内の佐久
シルト層の構造は, 北縁では約 $45^{\circ} \mathrm{N}$ の傾斜で盆地床下 へ連続し, バルジの背後では $20^{\circ} \mathrm{S}$ の傾斜で上位の啋層 に覆われる. 堆積・変形後の侵食によって失われた部分 については上記の 2 つの傾斜が滑らかに連続するよう に推定されている [平川 $(1982,1992)]$. 丘陵内での佐久 シルト首は Fig. 2 の A 地点の露頭で約 $60 \mathrm{~m}$ にわたっ て 5 $8^{\circ} \mathrm{S}$ で傾斜しているのが観察できる. さらにその 南部では電気探査の資料から次第に傾斜を減じながら山 麓部まで連続すると考えられる [西宮・石田 (1967)]。

\section{2 市之瀬台地の地形と変動の特徽}

市之瀬台地は巨摩山地の東麓に位置し，そこから東流 する市之瀬川・深沢などによって形成された南北約 4 $\mathrm{km}$ 東西約 $3 \mathrm{~km}$ の扇状地が活断層による傾動隆起を受 けて形成された地形である. 地形面はFig. 3 のように台 地内で I, II, III 面に区分できる.

I 面は台地東縁部にムジナ丘, 上野山, 御殿山という 南北に連なる小丘列として認められる。このうちムジナ 


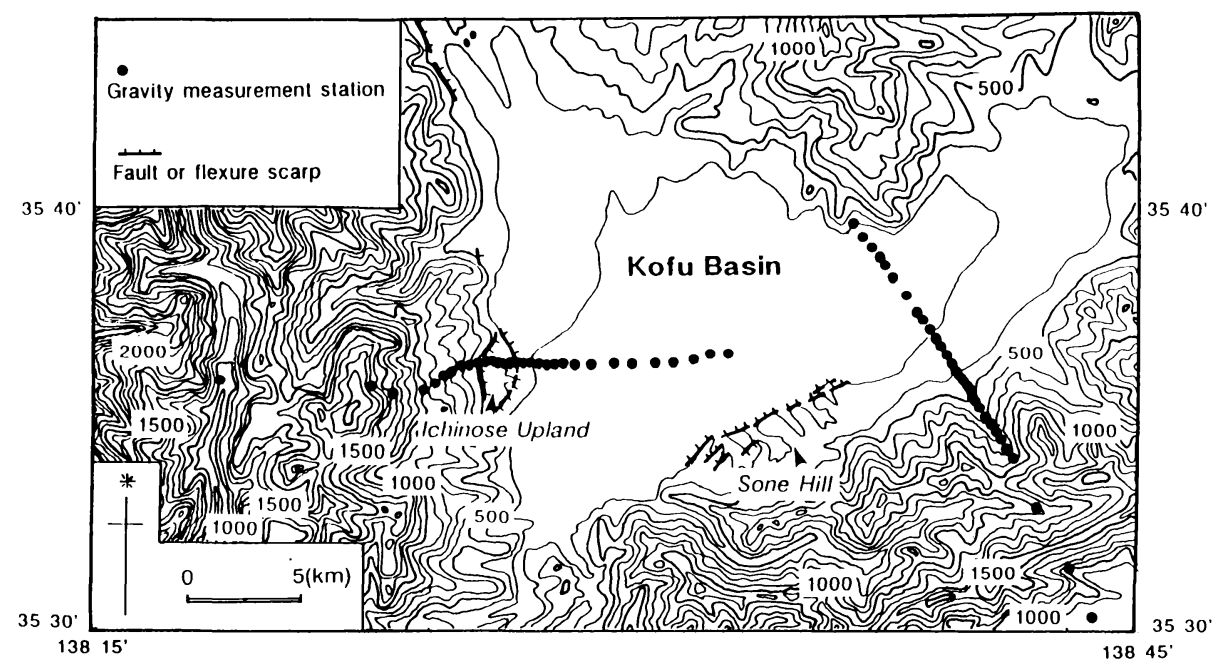

Fig. 4. Distribution of gravity stations in the study area. Gravity values are listed in Tables 1 and 2.

丘は宅地造成のために崎田 (1961) の時代にくらべて人 為的に削剝されている.これらの地形面の構成層は， マ トリックスが褐色の砂で, 淘汰が悪く風化の著しい中碟 サイズ以下の要角磁からなり, ムジナ丘, 深沢, 漆川, 湯沢, オモイ沢沿いの露頭で確認できる.この砂砂層は ところどころに砂層・泥層を挟む．これは扇状地形成時 の河道変遷による層相の変化に対応すると考えられるこ とから，櫛形山から東流する河川による扇状地性堆積物 と考えられる，漆川，堰の川，湯沢ではこの砂砂層が下 位の安山岩の基盤岩を不整合に覆っているのが露頭で観 察される，一方, 台地南部オモイ沢では硶首の下位は菲 崎泥流堆積物である。これより本論では I 面を崎田

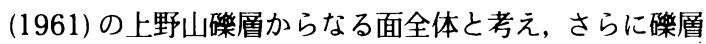
下位に安山岩基盤の認められる面をIa 面, 礫首下位に 韮崎泥流の認められる面を Ib 面之細分したＩ面構成層 の上位は風成の $\mathrm{Pm}-\mathrm{I}$ 軽石層を含む褐色風化火山灰に覆 われる [澤 (1981)]. 従って市ノ瀬台地の I 面は, 兽根丘 陵の II 面に対比でき, 形成時期は 8 万年前以前と考え られる.

II 面は台地北部に広がる標高 $350 \sim 500 \mathrm{~m}$ の面で甲 府盆地第四紀研究グループ (1969) の伝嗣院面に相当す る.この面を構成する碩層はひん岩·凝灰角䃇岩の中程 度の亜角磁からなる首厚 $30 \mathrm{~m}$ 以上の扇状地性堆積物で ある. I 面構成啋層に比べると全体に未風化である. 台 地中部の深沢川が刻む谷中では II 面構成磻層が I 面構 成磘層を不整合に㻼っているのが露頭で観察できる。さ らに, 同様な砂磻層から構成される II 面相当面は深沢川 扇頂部右岸や市之瀬川扇頂部左岸にも分布する. II 面の 形成時期は, 深沢沿いの露頭で地表より約 $20 \mathrm{~m}$ 下部に
層厚 $10 \mathrm{~cm}$ ほどの Pm-I 軽石層が砂層中にはさまれる [澤 (1981)］ことから，5８万年前と考えられる.

III 面は甲府盆地第四紀研究グループ (1969) の市之瀬 川面に相当し, 台地の中央部から南西部にかけて分布す る.ただし台地西部では古い面を覆って，台地東部では 逆にこれを切って発達する．この面を構成する磁層は土 石流性堆積物の様相を呈し, 台地西部の露頭では I 面構 成砂層を厚さ 1 2 $\mathrm{m}$ で覆っているのが観察される，砂 層の上位には火山灰層か認められないことから，この面 は兽根丘陵の IV 面に相当し形成時期は 2 万年以降と考 えられる。ただし，活断層によるIII 面の変形が II 面に 比へててはるかに小さいことから，完新世に形成された可 能性もある. 現在の市之瀬川や漆川は，III 面をさらに刻 んで流下している.

曽根丘陵の場合と異なり，市之瀬台地では活断層によ る变位地形が台地前縁と山麓の 2 ケ所に認められる.

台地前縁では, 北部の II 面, 中央部の III 面, 南部の Ib 面に顕著な撓曲変形がみられ，ムジナ丘および上野山 の背後の扇状地面は山地側へ逆傾斜している。一方台地 の山麓では, III 面が比高約 $20 \mathrm{~m}$ の低断層崖で明瞭に切 られている.

また，市之瀬台地の北方約 $4 \mathrm{~km}$ ，釜無川の支流御勅 使川右岸において, 河成段丘の前縁部に著しい撓曲変形 が見られる．この段丘面は風化した亜角砂を含む砂砂層 から構成されるが, 地表から約 $5 \mathrm{~m}$ 下部の喽層中に Pm-I を挟む.これよりこの面は Pm-I 軽石層降下後まも なく離水したと考えられ，年代は 7〜8万年前と見積ら れる.この撓曲を生じさせた活断層は地形的に市之瀬台 地前縁の活断層に連続しており,さらに北方では釜無川 
Table 1. Gravity measurements across the Sone Hills.

\begin{tabular}{|c|c|c|c|c|c|c|c|}
\hline No. & $\begin{array}{l}\text { Lati } \\
\text { deg. }\end{array}$ & $\begin{array}{l}\text { itude } \\
\text { min. }\end{array}$ & $\begin{array}{l}\text { Long } \\
\text { deg. }\end{array}$ & $\begin{array}{l}\text { itude } \\
\text { min. }\end{array}$ & $\begin{array}{r}\text { Altitude } \\
\text { m }\end{array}$ & $\begin{array}{r}\text { Obs.grav. } \\
\text { gal }\end{array}$ & $\begin{array}{r}\text { B.anomaly } \\
\text { mgal }\end{array}$ \\
\hline 1 & 35 & 39.64 & 138 & 36.73 & 292.99 & 979.70742 & -16.92 \\
\hline 2 & 35 & 39.46 & 138 & 36.88 & 270.12 & 979.71148 & -18.36 \\
\hline 3 & 35 & 39.26 & 138 & 37.05 & 262.16 & 979.71235 & -19.23 \\
\hline 4 & 35 & 39.01 & 138 & 37.24 & 262.16 & 979.71000 & -21.76 \\
\hline 5 & 35 & 38.77 & 138 & 37.45 & 262.25 & 979.70801 & -23.68 \\
\hline 6 & 35 & 38.49 & 138 & 37.70 & 263.37 & 979.70661 & -24.64 \\
\hline 7 & 35 & 38.11 & 138 & 38.06 & 261.06 & 979.70734 & -23.87 \\
\hline 8 & 35 & 37.76 & 138 & 38.38 & 267.59 & 979.70718 & -22.22 \\
\hline 9 & 35 & 37.43 & 138 & 38.65 & 275.13 & 979.70674 & -20.51 \\
\hline 10 & 35 & 37.07 & 138 & 38.93 & 295.85 & 979.70399 & -18.64 \\
\hline 11 & 35 & 36.75 & 138 & 39.17 & 323.85 & 979.70000 & -16.49 \\
\hline 12 & 35 & 36.57 & 138 & 39.33 & 348.79 & 979.69576 & -15.51 \\
\hline 13 & 35 & 36.39 & 138 & 39.46 & 365.99 & 979.69270 & -14.76 \\
\hline 14 & 35 & 36.22 & 138 & 39.57 & 386.13 & 979.68894 & -14.13 \\
\hline 15 & 35 & 36.10 & 138 & 39.67 & 399.77 & 979.68645 & -13.55 \\
\hline 16 & 35 & 35.98 & 138 & 39.75 & 417.13 & 979.68320 & -13.01 \\
\hline 17 & 35 & 35.88 & 138 & 39.82 & 428.93 & 979.68116 & -12.38 \\
\hline 18 & 35 & 35.80 & 138 & 39.87 & 437.91 & 979.67965 & -11.75 \\
\hline 19 & 35 & 35.74 & 138 & 39.94 & 448.99 & 979.67456 & -11.15 \\
\hline 20 & 35 & 35.63 & 138 & 40.04 & 468.57 & 979.67117 & $-10 \cdot 14$ \\
\hline 21 & 35 & 35.52 & 138 & 40.18 & 489.05 & 979.66826 & -9.00 \\
\hline 22 & 35 & 35.42 & 138 & 40.27 & 504.73 & 979.66471 & -8.24 \\
\hline 23 & 35 & 35.30 & 138 & 40.36 & 525.38 & 979.66062 & -7.21 \\
\hline 24 & 35 & 35.16 & 138 & 40.47 & 549.58 & 979.65282 & -5.87 \\
\hline 25 & 35 & 34.97 & 138 & 40.60 & 594.30 & 979.64825 & -4.37 \\
\hline 26 & 35 & 34.83 & 138 & 40.70 & 620.02 & 979.63999 & -3.54 \\
\hline 27 & 35 & 34.66 & 138 & 40.82 & 664.70 & 979.63148 & -2.97 \\
\hline 28 & 35 & 34.49 & 138 & 41.00 & 713.17 & 979.61576 & -1.96 \\
\hline 29 & 35 & 34.23 & 138 & 41.24 & 797.02 & 979.60231 & -1.06 \\
\hline 30 & 35 & 34.05 & 138 & 41.40 & 865.06 & 979.58251 & -0.35 \\
\hline 31 & 35 & 32.91 & 138 & 42.06 & 964.69 & 979.58300 & 1.19 \\
\hline 32 & 35 & 30.49 & 138 & 43.75 & 946.90 & 979.58850 & 5.35 \\
\hline 33 & 35 & 31.49 & 138 & 43.10 & 833.70 & 979.61400 & 6.35 \\
\hline
\end{tabular}

右岸菲崎付近の活断層に連続すると思われる.

\section{§3. 重力異常からみた曽根丘陵・市之瀬台地の浅部 地下構造}

\section{1 重力測定および解析の方法}

重力異常の分布が大地形に認められる地質境界や構造 線之密接に関係することについてはこれまで多くの報告 がある [例えば, 河野 (1983)]. 活断層研究においても, 重力異常解析をむちいることは, 地表に現れない活断層 の検出だけでなく，断層パラメー夕に関する定量的議論 の可能性という点でも有効と思われる。例えば池田 (1992) は断層を横切る精密重力測定から伊那谷断層の 浅部地下構造と総変位量を求めている.

しかし，本論調査地域およびその周辺におけるこれま での重力探査は, 主として南部フォッサマグナにおける 糸魚川-静岡構造線全体といった大地形を対象としたも のが多く [Ү Амамото et al. (1982), 里村・安間 (1986), SA TOMURA (1989), 萩原 (1990), 駒澤ほか (1991)], 個々の活断層に関わる地下構造を議論する探査精度を持 ち合わせていなかった，そこで本論では曽根丘陵および 市之瀬台地に認められる活断層を横切る高密度な重力測 定点を新たに設定した (Fig. 4). 重力測定点は地形的に
推定される活断層の走向にほぼ直行する方向とし, 測点 間隔は活断層の近傍では $200 \sim 300 \mathrm{~m}$ ，その他では 500 $\sim 1000 \mathrm{~m}$ 程度とした. 曾根丘陵では測定点数 32 点 (Table 1) で測線長は約 $20 \mathrm{~km}$ ，市之瀬台地では測定点 数 25 点 (Table 2) で測線長は約 $8 \mathrm{~km}$ となった.

使用した重力計は La Coste \& Romberg 社製 G-283 重力計である. 重力観測值は, 甲府市丸の内の国土地理 院一等水準点での重力值 $979.707379 \mathrm{gal}$ をもとにして 求めた．各測定点の標高は国土地理院の一等水準点を標 高基準とし自動レベルによる水準測量により測定した。 ブーゲー異常値を得るために, 潮汐・ドリフト・緯度・ 地形・フリーエアー・ブーゲーの各補正を施した。地形 補正に関しては, 測点より $0.5 \mathrm{~km}$ 以上 $60 \mathrm{~km}$ 内は標高 読取デイジタルデータをむちい，距離に応じた格子間隔 (東西 $3^{\prime} \sim 11.25^{\prime \prime}$, 南北 $2^{\prime} \sim 7.5^{\prime \prime}$ ）の同心円柱近似, 20 $\mathrm{m}$ 以上 $500 \mathrm{~m}$ 内は $1 / 25,000$ 地形図の読取値をもちい た $200 \mathrm{~m}$ 間隔の同心円柱近似，さらに測定点周辺 $20 \mathrm{~m}$ 内は地形の凹凸をスケッチで断面に表示して補正した。

本論で検討対象とするのは，甲府盆地内の盆地堆積物 之周辺山地の基盤岩類之の密度差を反映した構造であ る.このため観測値から堆積層の基底より深い部分 （中・下部地殼や上部マントル）に原因をもつ広域的な 
Table 2. Gravity measurements across the Ichinose Uplan.

\begin{tabular}{|c|c|c|c|c|c|c|c|}
\hline No. & $\begin{array}{l}\text { Lat } \\
\text { deg }\end{array}$ & $\begin{array}{l}\text { tude } \\
\text { min. }\end{array}$ & $\begin{array}{l}\text { Lon: } \\
\text { deg }\end{array}$ & $\begin{array}{l}\text { itude } \\
\text { min. }\end{array}$ & $\begin{array}{r}\text { Altitude } \\
\text { m }\end{array}$ & $\begin{array}{r}\text { Obs.grav. } \\
\text { gal }\end{array}$ & $\begin{array}{r}\text { B.anomaly } \\
\text { mgal }\end{array}$ \\
\hline 1026 & 30 & 35.87 & 138 & 18.78 & 942.09 & 979.70738 & -20.74 \\
\hline 1027 & 35 & 35.86 & 138 & 23.25 & 1396.64 & 979.68606 & -21.08 \\
\hline 1 & 30 & 35.72 & 138 & 23.86 & 1468.12 & 979.44914 & -22.75 \\
\hline 2 & 35 & 35.71 & 138 & 24.59 & 941.57 & 979.55604 & -28.06 \\
\hline 3 & 35 & 35.82 & 138 & 24.93 & 878.11 & 979.56908 & -31.33 \\
\hline 4 & 35 & 35.90 & 138 & 25.24 & 706.50 & 979.60012 & -32.70 \\
\hline 5 & 35 & 35.96 & 138 & 25.43 & 603.22 & 979.61729 & -33.86 \\
\hline 6 & 35 & 36.03 & 138 & 25.63 & 562.51 & 979.62543 & -34.74 \\
\hline 7 & 35 & 36.09 & 138 & 25.82 & 523.62 & 979.63405 & -35.63 \\
\hline 8 & 35 & 36.12 & 138 & 26.00 & 500.40 & 979.63945 & -36.57 \\
\hline 9 & 35 & 36.13 & 138 & 26.11 & 480.61 & 979.64326 & -37.19 \\
\hline 10 & 35 & 36.11 & 138 & 26.30 & 453.19 & 979.64855 & -37.87 \\
\hline 11 & 35 & 36.09 & 138 & 26.54 & 419.63 & 979.65470 & -38.85 \\
\hline 12 & 35 & 36.08 & 138 & 26.78 & 396.79 & 979.65922 & -39.31 \\
\hline 13 & 35 & 36.08 & 138 & 27.00 & 378.55 & 979.66219 & -40.20 \\
\hline 14 & 35 & 36.07 & 138 & 27.19 & 358.87 & 979.66533 & -41.09 \\
\hline 15 & 35 & 36.06 & 138 & 27.40 & 337.68 & 979.66833 & -42.47 \\
\hline 16 & 35 & 36.06 & 138 & 27.55 & 318.48 & 979.67174 & -43.06 \\
\hline 17 & 35 & 36.07 & 138 & 27.72 & 302.69 & 979.67421 & -43.96 \\
\hline 18 & 35 & 36.06 & 138 & 27.93 & 290.89 & 979.67610 & -44.63 \\
\hline 19 & 35 & 36.08 & 138 & 28.15 & 279.44 & 979.67816 & -45.04 \\
\hline 20 & 35 & 36.11 & 138 & 28.41 & 275.76 & 979.67911 & -45.15 \\
\hline 21 & 35 & 36.11 & 138 & 28.80 & 273.56 & 979.67970 & -45.33 \\
\hline 22 & 35 & 36.09 & 138 & 29.21 & 261.72 & 979.68263 & -44.96 \\
\hline 23 & 35 & 36.09 & 138 & 29.81 & 254.71 & 979.68514 & -44.13 \\
\hline 24 & 35 & 36.09 & 138 & 30.35 & 255.74 & 979.68611 & -43.22 \\
\hline 25 & 35 & 36.16 & 138 & 31.19 & 259.74 & 979.70738 & -42.83 \\
\hline 1086 & 35 & 36.15 & 138 & 31.57 & 254.03 & 979.68700 & -42.53 \\
\hline 1088 & 35 & 36.30 & 138 & 32.92 & 252.20 & 979.68800 & -42.47 \\
\hline 1089 & 35 & 36.71 & 138 & 33.75 & 252.81 & 979.69000 & -40.79 \\
\hline 1090 & 35 & 36.78 & 138 & 34.58 & 253.75 & 979.69200 & -38.82 \\
\hline
\end{tabular}

成分を除去しなければならない，本論のように測線長が $10 \sim 30 \mathrm{~km}$ 程度の中でこのような広域的な重力異常を 生じさせる原因は, 主として日本列島の下に沈み込む フィリピン海プレートや太平洋プレートの高密度のスラ ブによる効果であると考えられる。 EL-IBIARY and HAGIWARA（1987）は東北・中部日本の密度構造を解析 した中で，両プレートの沈み込みによって太平洋側から 内陸へ傾き下がる広域的な重力異常が生じることを示し た．本論では調查地域の広域成分としてこの結果を用 い, 観測值から差し引くことで浅部密度構造を反映する 残差成分を得た。

基盤岩石の密度はブーゲー異常值と地形の相関の最も 小さい $2.67 \mathrm{~g} / \mathrm{cm}^{3}$ を仮定した。基盤岩石と盆地堆積物 の密度差については, 盆地堆積物が周辺基盤と同じ岩石 で構成されその孔隙率を $30 \%$ 程度とし，孔隙が水で充 填されていると仮定した場合の計算值約 $-0.5 \mathrm{~g} / \mathrm{cm}^{3}$ を 与えた。

こうして得られたブーゲー重力異常の残差成分に対 し, 二層密度構造を仮定し, タルワニの方法 [TALWANI et al. (1959)] を用いた計算值との差の二乗和が最も小さ くなるような浅部地下構造モデルを求めた.

\section{2 ブーゲ異常値の残差成分から推定される曽根丘 陵の地下構造}

兽根丘陵における重力異常の広域成分には EL-IBIARY and HaGrwara (1987)の結果より $1 \mathrm{mgal} / \mathrm{km}$ を仮定 した. 得られたブーゲー重力異常の残差成分は, 地形的 に認められる山地一盆地境界よりも約 $4 \mathrm{~km}$ 山地内から 相対的に減少し始め, 盆地の中央部付近で最小值をとり その後相対的に増加する (Fig. 5).

モデルの密度構造には高密度の基盤と低密度の盆地堆 積物が低角の逆断層で接するものを設定した，その密度 境界面の先端は, 兽根丘陵での野外調査で最も盆地より に基盤か確認された山地一盆地の地形境界（境界断層の 位置に一致）に固定した. 計算過程において密度境界面 の形状を变化させ, 観測值に最む適合する構造を求め た. その際, 盆地内での堆積物の形状については, 海野 (1981)が示した重力測線にほぼ平行する地質断面の盆 地堆積物の形状に調和させた. Fig. 5 に示すように計算 結果は仮定密度構造が比較的単純であるにもかかわら ず，観測值と計算值の差は御坂山地内の観測点を除いて $0.2 \mathrm{mgal}$ 以内となりょく適合した。

以上の結果より, 山地内から境界断層へ向かってブー ゲー異常值が減少するのは, 低密度層が逆断層運動に よって山地内にくさび状に入り込んだ構造に起因すると 


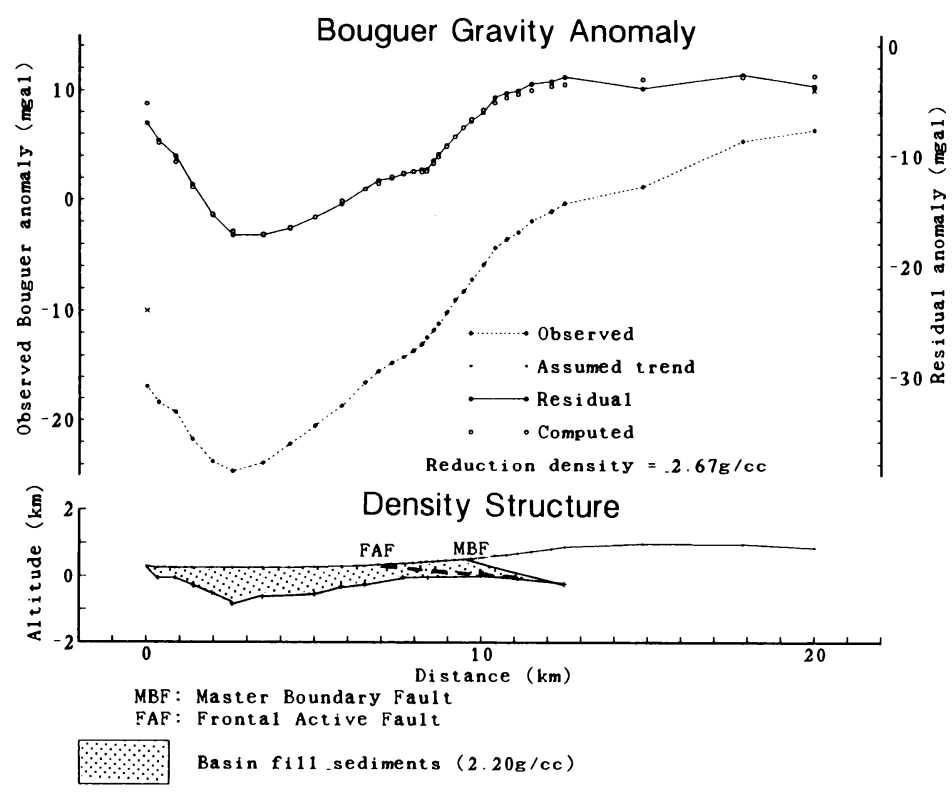

Fig. 5. Bouguer gravity anomaly across the Sone Hills, and best-fit two-dimensional density structure deduced from the gravity anomaly. See Fig. 4 for the location of the profile. Observed Bouguer gravity values are shown by solid circles connected with thick dotted lines. Residual gravity values are shown by solid circles connected with solid lines, assuming general gravity trend (thin dotted straight line) caused mainly by subducted oceanic slabs beneath Honshu from the Pacific side. Open circles indicate gravity values computed for the best-fit density structure.

解釈できる．境界断層の傾斜を高角にしたり北傾斜（正 断層）にした場合には，境界断層近傍 2〜3 km 以内での ブーゲー異常のパターンをうまく再現できないので, こ の結論は動かしがたいと考えられる. また测線北端付近 でのブーゲー異常値の増加は盆地北部の山地をなす基盤 の影響と考えられる. また，御坂山地内で相対的に誤差 が大きい理由は, 観測点が山間盆地に位置するために段 丘堆積物や崖鍾堆積物等による局地的な密度異常が存在 するためか，あるいは基盤岩石自体の密度が一様でない ためと考えられる.

最適解における御坂山地内での基盤と盆地堆積物との 密度境界面の傾斜は少なくとあ地下 $1 \sim 2 \mathrm{~km}$ までは約 $10^{\circ}$ と推定され, その水平短縮の総変位量は約 $4 \mathrm{~km}$ に およぶ.この值は御坂山地の荷重による盆地堆積物の圧 密の効果を無視しているので, 実際にはこの值より大き いと考えられる.

既に述べたように, 曽根丘陵とその背後の御坂山地を 境する境界断層が第四紀に活動した証拠はなく，後期更 新世以降の兽根丘陵における変動は丘陵前縁部に集中す る.しかし得られた浅部地下構造では, 丘陵前縁下部の 基底不整合面（Fig. 5 の FAF 付近）に顕著な変形構造 はみられない.これは丘陵前縁部に変形を生じさせる前 縁活断層が, 境界断層より盆地堆積物内に派生したデコ
ルマンであるためと考えられる．この場合前縁断層の傾 斜角は約 $5^{\circ}$ と推定される.このような構造は池田・米 倉 (1979) の逆断層の低角化モデルと調和的である.

\section{3 ブーゲ異常値の残差成分から推定される市之瀬 台地の地下構造}

EL-IBIARY and HAGIWARA (1987) の結果より，市之瀬 台地における重力異常の広域成分は測線方向に 0.76 $\mathrm{mgal} / \mathrm{km}$ を仮定した. 得られたブーゲー重力異常の残 差成分は, 市之瀬台地の背後巨摩山地内で山地一台地の 地形境界より約 $5 \mathrm{~km}$ 山地内の地点から相対的に減少し 始め, 台地前縁部で最小值をとり, その東でほぼ一定と なる (Fig. 6).

2 章で述べたように，市之瀬台地では台地前縁部に背 後山地と同じ基盤岩が観察される.ここでは低角逆断層 の密度境界面の先端を台地前縁部に位置させるモデルを 仮定し計算をおこなった. 計算結果はFig. 6 に示す. モ デルの単純な構造にもかかわらず, 観測値之計算值の差 は山地内のいくつかの観測点を除くと約 $0.2 \mathrm{mgal}$ 以下 となり，よく適合する.

以上の結果から, 巨摩山地内から市之瀬台地東縁へか けてのブーゲー異常値の減少の理由についても, 曽根丘 陵の場合之同様に, 台地の成因に逆断層運動が関与し, 盆地堆積物がくさび状に山地内に入り込んでいるためと 


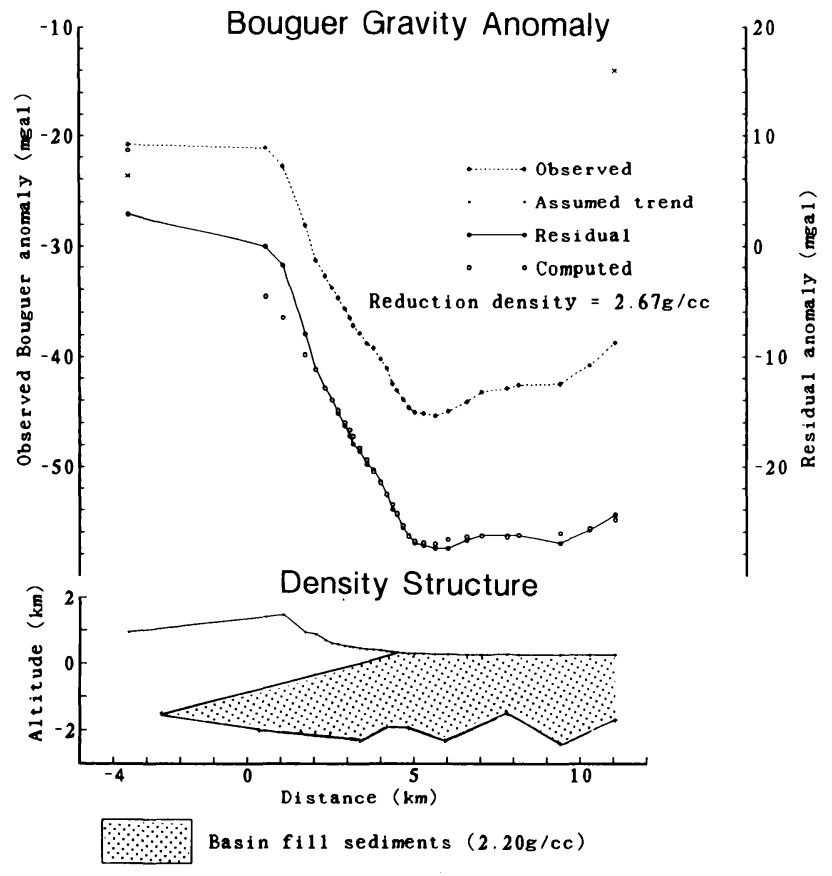

Fig. 6. Bouguer gravity anomaly across the Ichinose Upland, and best-fit two-dimensional density structure deduced from the gravity anomaly. See Fig. 4 for the location of the profile. Observed Bouguer gravity values are shown by solid circles connected with thick dotted lines. Residual gravity values are shown by solid circles connected with solid lines, assuming general gravity trend (thin dotted straight line) caused mainly by subducted oceanic slabs beneath Honshu from the Pacific side. Open circles indicate gravity values computed for the best-fit density structure.

考えられる. 巨摩山地内での誤差が大きい理由も, 曽根 丘陵における御坂山地内の誤差と同様に, 局地的な密度 異常の影響と考えられる.

モデルの結果では市之瀬台地を横切る断面での仮定密 度構造の盆地堆積物最深部は地表下約 $2 \mathrm{~km}$ となる。市 之瀬台地周辺では基盤まで到達したボーリングのデータ はない.しかし海野 (1981)のボーリング資料解析結果 によれば, 盆地内では南西部ほど沈降が著しい傾向があ り，盆地中央部ですでに基盤が地表下約 $600 \mathrm{~m}$ に位置 する. したがって密度構造から推定した上記の基盤深度 の値は妥当と考えられる.

市之瀬台地では, 兽根丘陵の場合と異なり, 山地一盆地 の地形境界にも新期の扇状地面を切る断首崖が観察され る (Fig. 3). しかしこの地形境界において密度構造に顕 著な変形が認められない。したがって,この地形境界部 の活断層は, 主断層から派生した副次的な逆断層, また は主断層の動きに伴って生じた地滑り性の正断層である と考えられる. しかし，これが正断層か逆断層かを露頭 で確認することはできなかった。

以上の結果から, 山地内の基盤岩と盆地堆積物との密 度境界面の傾斜は約 $18^{\circ}$ と見積られ, 兽根丘陵に比べて
高角である. 低密度の盆地堆積物は台地前縁より約 5 $\mathrm{km}$ 以上も巨摩山地内へ入り込んでいると考えられる. 市之瀬台地内では井戸掘削のために比抵抗法を用いた 地下探査が行われている [櫛形町役場資料, 未公表]. こ れによると，台地内では地表より 150 200 $\mathrm{m}$ まで扇状 地磻層が存在し, その下位に凝灰角砅岩からなる基盤が 存在することが予想される. 先のモデルでは, 基盤上位 の扇状地堆積物を考慮していないが，比抵抗探查の結果 を組み入れたモデルあおおよそのパターンは一致する. よって基盤の先端が台地前縁部に位置するとした仮定は 妥当であると考えられる.

以上のことは, 市之瀬台地が地形的には曽根丘陵と類 似していてあ, 基盤と盆地堆積物との境界断層の位置が 異なっていることを意味する. 市之瀬台地の地形面は曽 根丘陵の地形面に比へて全体に新しく, 境界断層の位置 の違いは山地と盆地の分化に関する逆断層運動の発達史 の異なったステージにあることが原因と考えられる.今 後は, 逆断層の垂直成分による地形の分化だけでなく, 地形境界の位置の水平移動も考慮した構造発達史の解明 が必要であろう. 

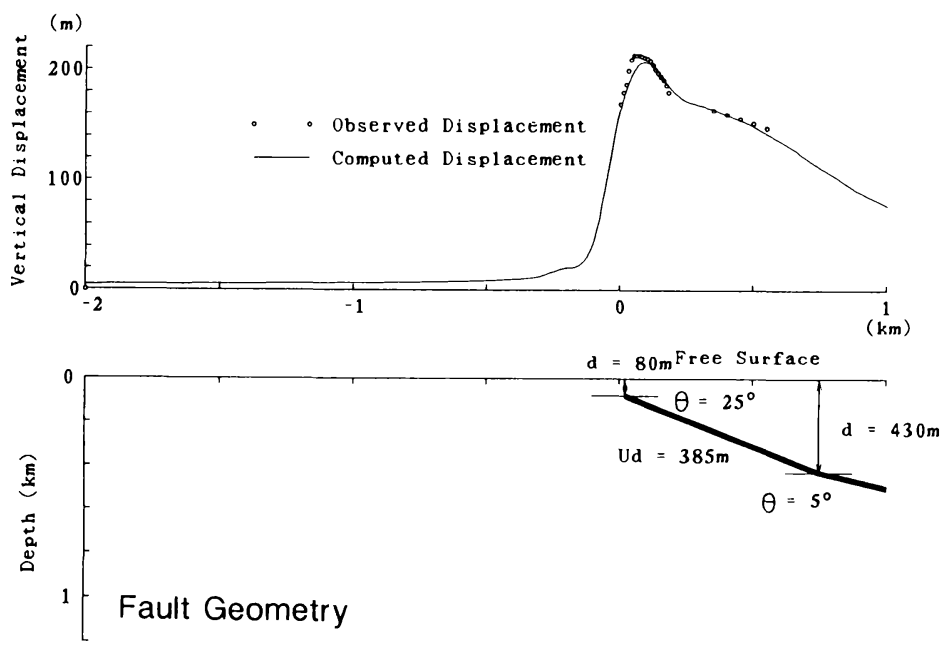

Fig. 7. Observed and computed surface deformation across the frontal active fault of the Sone Hills. The line of profile passes locality A in Fig. 2. Open circles indicate observed vertical displacements of the Saku silt bed ca. 300-350 ka. Solid curve indicates computed vertical displacements.

\section{§4. 断層モデルをもちいたネットスリップの推定}

\section{1 断層モテルと活断層の变形パターン}

MANSINHA and SMYLIE (1971) は, 半無限弾性体中の 任意の傾きをむつ断層面上での変位に伴って生ずる準静 的な地表变形を計算する簡明な解析的表現式を提示し た。半無限弾性体を仮定した断層モデルをあちいて計算 した準静的変形は，地震に伴う地款の変形の有効な第一 次近似であると考えられ，実際の地震時に観測された地 表変形に対しこのような断層モデルをあちいて，断層面 の形状・スリップ量等の断層パラメータの決定がなされ てきた

しかしこのモデルが断層運動のくりかえしによって形 成される地形・地質構造の変形に関しても適応できるか については議論を必要とする．例えば，逆断層の動きに よって山地の隆起が生ずると，これに伴う余剩な加重に より隆起域を中心とするかなり広い範囲でアイソス夕 テックな沈降がおこる．また，断首面の末端部に生ずる 応力集中は粘性流動により緩和され，これに伴って緩慢 で比較的広域的な変形が生じ得る。しかし，段丘面の変 形といった小さな地形スケールでの変形のパターンにつ いては，断層モデルから得られる変形パ夕ーンと比較す ることで断層パラメータを決定することができると考え られる。例えば渡辺 (1985) は福島盆地周辺の活構造に ついて，断層線の形態から推定された断層パラメータを 持つモデルの変位パターンが，侵食平坦面の高度分布お よび深井戸資料から得た地下構造の変形と調和すること を示した。

以下では, 畺根丘陵および市之瀬台地の地形面と構成
層の変形を観測値とし, 前章でブーゲー重力異常解析よ り求めた浅部地下構造を拘束条件として, 断層モデルを もちいて活断層のネットスリップ速度を決定する．断層 運動による累積変位は弾性変形であったと仮定する。

\section{2 曽根丘陵の変形と活断層のネットスリップ速度}

2 章で述べたように曽根丘陵の変位地形は非常に短波 長なテクトニックバルジと扇状地面の逆傾斜が特徵であ り，低角の逆断層が推定されている [澤 (1981)]. ブー ゲー重力異常解析からこの変形を生じさせた前縁断層の 傾斜は約 $5^{\circ}$ と見積られた. 地表变形の観測量として, 絶 対年代と变形構造が最も良く明らかとされている佐久シ ルト層の变形を用いた。佐久シルト層の年代は, 狭在す る火山灰層が大町 Apm に対比されることから, 約 30〜 35 万年前と推定されている [SUZUKI (1991)]。佐久シル 卜層の丘陵内の变形についてはこれまでの研究報告 [西 宮・石田 (1967), 平川 $(1982,1992)]$ や露頭での観察か ら推定した。堆積後の絶対的な変位については, 断層モ デルから傾斜角が $15^{\circ}$ 以下の低角逆断層では下盤側の沈 降量がほとんど無視できる [MANSINHA and SMYLIE (1971)］ことから，丘陵から約 $2 \mathrm{~km}$ 北へ離れたボーリ ング地点での佐久シルト層の標高 [海野 (1981)] を堆積 時の地表としその後の変動の影響を受けない固定点と仮 定した。そして丘陵内で観察された佐久シルト層の標高 から固定点の標高を差し引いた值を，堆積後 30 万年間 の断層運動による累積変位であると考えた。

モデルの断層面の傾斜角は，ブーゲー重力異常解析か ら得た前緣断首の $5^{\circ}$ をえ, 先端の位置もこれに調和 させた。 ただし撓曲変形を再現するために断層面の先端 


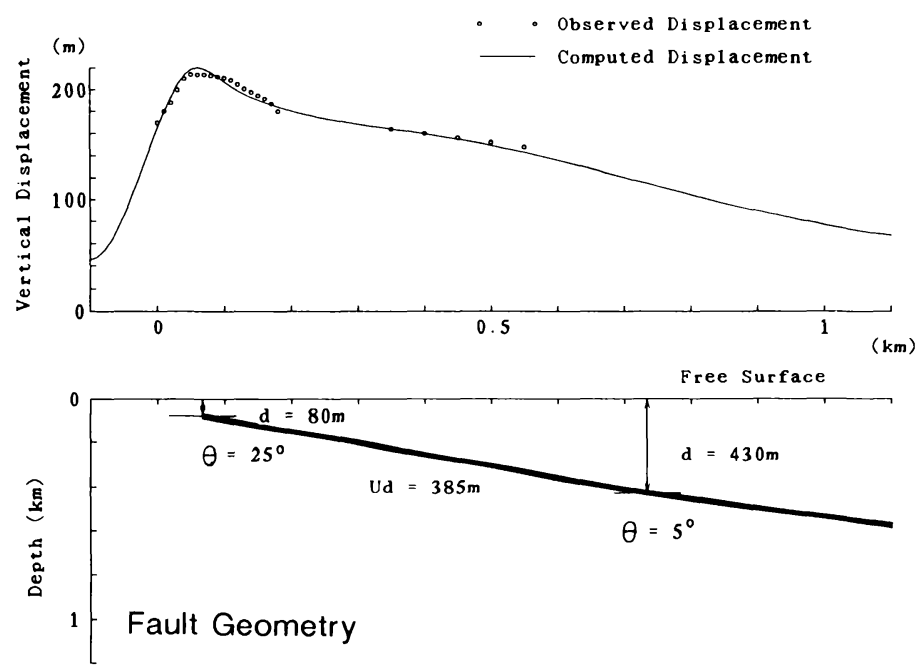

Fig. 8. Same as Fig. 7, but showing details near the tectonic bulge.

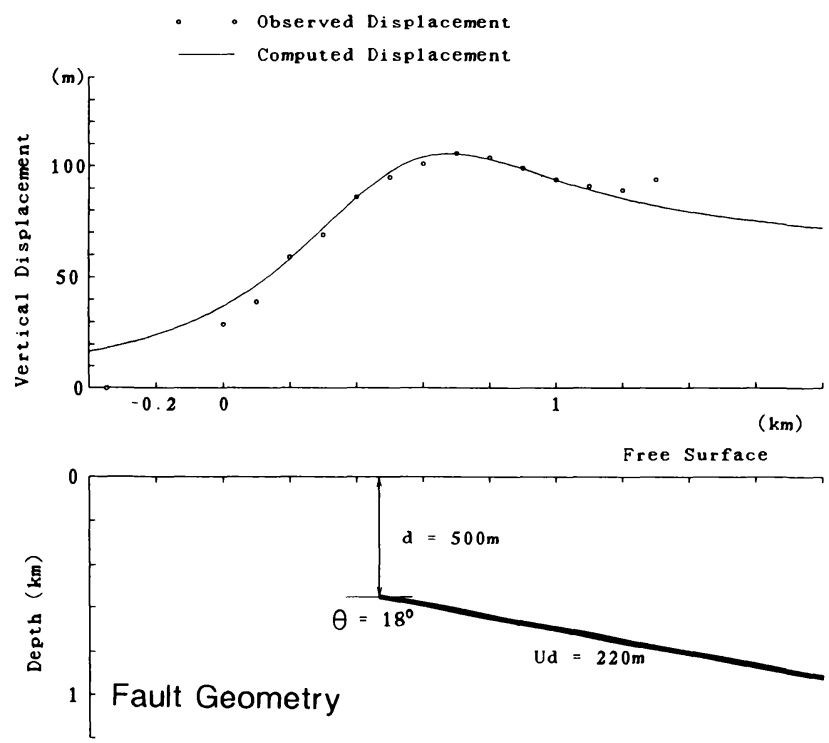

Fig. 9. Observed and computed surface deformation across the active fault at the eastern margin of the Ichinose Upland. Open circles indicate observed vertical displacements that occurred during the period from ca. $50 \mathrm{ka}$ to ca. $20 \mathrm{ka}$. Solid curve indicates computed vertical displacements.

は地表に到達させていない. またここでは断層面の先端 近傍での局地的な変形を対象とするので, モデルの断層 面の幅は $20 \mathrm{~km}$, 長さは地表での断層線とほぼ同じ 15 $\mathrm{km}$ として断層線中央部での変形を計算した。 変位の向 きは, 地形的に横ずれ運動の証拠が認められないことか ら, 純粋な逆断層成分のみを与えた. 以上の仮定のもと で, 佐久シルト層の変形と調和する断層面上でのネット スリップ量を求める.
しかし,このような地下構造をあち総変位量だけをパ ラメータとしたモデルでは, 佐久シルト層のバルジ内の 変形構造と丘陵内部での逆傾斜を同時に満足することは できなかった。これは丘陵前縁のバルジの波長が, 仮定 した断層面の幅に比べて短すぎるためである，そこでバ ルジ構造は丘陵内で主断層から派生したやや高角の副次 断層によって形成されたと考えるモデルを作成した。 こ のような派生断層の例は, RODGERS and RIZER (1981) 


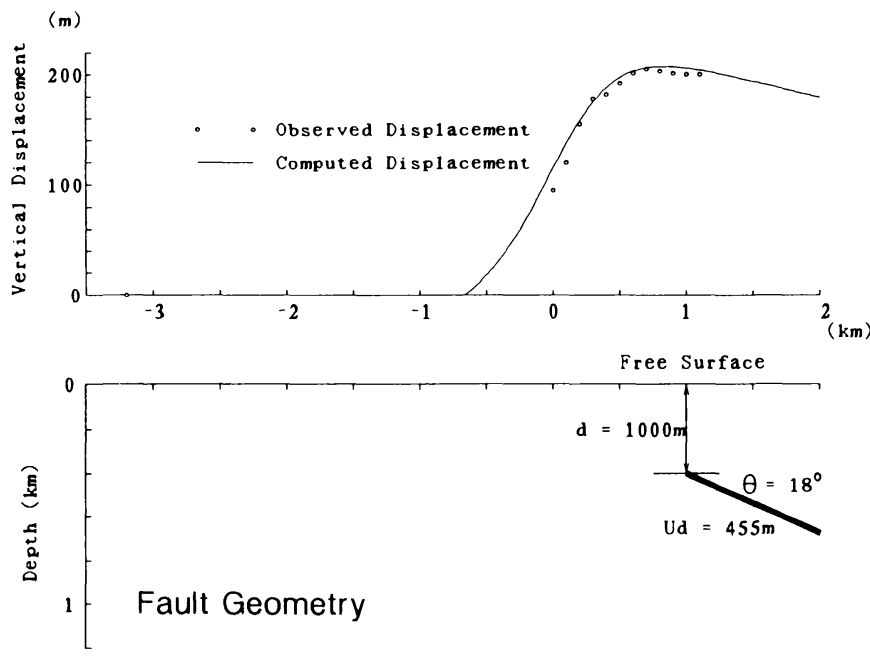

Fig. 10. Observed and computed surface deformation along Midai River north of the Ichinose Upland. See Fig. 3 for location. Open circles indicate observed vertical displacements of the river terrace ca. 70-80 ka. Solid curve indicates computed vertical displacements.

によって断層面の先端が地表に到達しない場合の断層面 先端付近に生ずる局所的な歪変化に起因する現象として 示されている，以上の場合，主断層と派生断層の变位量 が同じであるとすると末知の断層パラメータは主断層の 先端の位置, 派生断層の傾斜角と幅, 断層の総変位量の 4つである.これらを組み合わせて計算した時，観測值 を最も良く説明した結果を Fig. 7 に，バルジ周辺の拡大 図をFig. 8 に示す。これから判るように，単純な断層ジ オメトリにあかかわらず, 観測值と計算値は良く一致す る.このことは重力異常データと断層モデルから推定し た断層パラメータが実際の值に非常に近いことを意味す ると考えられる.

この結果より兽根丘陵内の活断層の過去約 30 万年間 の総変位量は $385 \mathrm{~m}$ と見積られ，この期間のネットス リップ速度は約 $1.3 \mathrm{~mm} / \mathrm{yr}$ と計算される.

\section{3 市之瀬台地の変形と活断層のネットスリップ速} 度

市之瀬台地に関しては, 兽根丘陵での佐久シルト層の ような良好な変位基準となる地層が存在しない。そこ で, 地表変形の観測量として, 地形面の高度分布を用い た. Fig. 3 の市之瀬台地の地形区分図で, 台地の主に北 部に分布し撓曲変形の顕著な II 面とそれを刻むIII 面の それぞれの扇状地形成時の原傾斜は同じであったと仮定 する.このとき，現在の II 面の標高から III 面の標高を 差し引いた值と, II 面形成から III 面形成までの期間の 盆地床埋積による扇状地形成の基準面の変化量の合計 を，両面の時代間隙である 3〜4 万年間の断層運動によ る垂直変位量とみなした，盆地床埋積量に関しては，両
面を構成する砂碟層がともに甲府盆地床下の堆積物の上 部碟層（約 10 万年前から堆積）に対比されること [海野 (1981)］ から, 堆積速度を一定と仮定して, 台地遠方で のボーリング資料より得られた上部磷層基底深度の $1 / 3$ の値を与えた。このようにして見積った垂直変位のパ ターンは台地前縁部で撓曲変形を示す (Fig. 9).

モデルの断層面の傾斜角はブーゲー重力異常解析より 求めた $18^{\circ}$ 与え, 先端を台地前縁部に位置させた。 し かし, 地表での撓曲変形を説明するために断層面の先端 は地表に到達させていない. 断層面の幅は, 曽根丘陵の 場合と同様に $20 \mathrm{~km}$ を仮定し，長さは地表で追跡でき る断層線の長さにもとづき $10 \mathrm{~km}$ を与えて，断層線中 央部での変形を計算した。市之瀬台地の場合には観測値 の水平方向の分布範囲がモデルに対して不十分なので, 曽根丘陵の場合ほよ゙一意的に総変位量を決定できない が，その中で最も良く適合した解を Fig. 9 に示す.

これから判るように, 市之瀬台地の場合も比較的単純 な断層ジオメトリの仮定で観測値を説明できる. 断層面 の先端の位置も重力異常データから推定した構造と調和 する. 3〜 4 万年間の断層総変位量は $250 \mathrm{~m}$ と計算さ れ，ネットスリップ速度は $6.3 \sim 8.3 \mathrm{~mm} / \mathrm{yr}$ と見積られ る.

また，市之瀬台地前縁断層の北方延長上に位置する御 勅使川右岸の河成段丘前縁部の撓曲変形にも，断層面の 傾斜角を先と同じ $18^{\circ}$ として同様のモデル計算をおこ なった (Fig. 10). 断層面先端の深さが市之瀬台地前縁部 の結果に比べてやや深くなっているが，全体にほぼこれ に連続するような低角な逆断層が地下に存在するという 
構造で地表変形の観測量を説明できる．この亡きネット スリップ速度は，地形面形成年代の誤差を考慮しても， $5.7 \sim 6.5 \mathrm{~mm} / \mathrm{yr}$ ．と見積られ，市之瀬台地 II 面の撓曲 変形から見積られた值と調和する.

以上のように甲府盆地西縁の活断層のネットスリップ の平均変位速度は盆地南縁に比べて 5 倍以上の值をむ つと考えられる。

\section{§5. 考察とまとめ}

甲府盆地の兽根丘陵および市之瀬台地にみられる活断 層について，ブーゲー重力異常解析より浅部地下構造を 推定し，さらに断層モデルをむちいて地表変形に調和す る断層のネットスリップ速度を計算した。 その結果, 兽 根丘陵の活断層は約 $1.3 \mathrm{~mm} / \mathrm{yr}$ ，市之瀬台地の活断層 は地形面の年代の誤差を考慮しても 6 8 mm/yr 程度 のネットスリップ速度を有することが明らかとなった。

従来, 傾斜ずれを主とする活断層の活動度は, 垂直ス リップ速度のみにもとづいて評価されてきた。しかし， 低角逆断層の場合には，見積りが困難な水平短縮成分が 卓越するので, 従来の方法では活動度を過小評価する可 能性がある、今後は，本報告で示したような断層の地下 構造も考慮した方法で，既知の活断層についても活動度 を再評価する必要がある.

フォッサマグナ西縁に沿う他の活断層の平均变位速度 については，主に横ずれ成分が卓越する松本盆地東縁の 活断層について $8.6 \pm 1.0 \mathrm{~mm} / \mathrm{yr}$ [IKEDA and YONEKURA (1986)], 諏訪盆地南東茅野付近の横ずれ活断層に ついて 7〜10 mm/yr [藤森 (1991)] と見積られている. このほか甲府盆地北方の円井衝上断層についても低位段 丘の変位より 3.5 $8 \mathrm{~mm} / \mathrm{yr}$ と推定されている [平川ほ か (1989)]. 大地形からこれらに連続すると考えられる 甲府盆地西縁の活断層について本論で求めたネットス リップ速度む，これらの值に調和する。これはフォッサ マグナ西縁の活断層の活動度が, 变位様式の違いにかか わらずほぼ一様であることを示し，一連の東西方向の圧 縮応力場のもとにあることを予想させる，これらの活断 層のネットスリップ速度は日本の内陸活断層の中で最大 級の値を示す.

一方, 兽根丘陵の活断層のネットスリップ速度はこれ らに比べて小さいが，それでも活動度 $\mathrm{A}$ 級に属する．ま た，活断層の走向と変位様式から推定されるテクトニッ クな応力場は, 北西一南東ないし北北西一南南東となり, 甲府盆地西縁の場合と大きく異なる。つまり甲府盆地 は，西縁と南縁に A 級活断層を生じさせるそれぞれ異 なる 2 つの応力場のもとで形成されており, 力学的なプ レートの三重会合域にあたる可能性がある.

\section{謝辞}

本研究を進めるにあたり, 東京大学理学部地理学教室 の米倉伸之教授をはじめとする諸先生に御指導頂いた。 現地調査では山梨大学教育学部の今泉俊文先生に御教示 頂いた. 東洋大学講師渡辺満久先生, 地理学教室大学院 の高田將志氏には論文構成について有益な助言を頂い た. また, 京都大学の岡田篤正先生, 西村 進先生には 原稿を査読いただき不備な点を御指摘頂いた。

以上の方々をはじめとして本研究に関しお世話になっ た方々に心より感謝します。

\section{文献}

浅川一郎・平川一臣, 1986, 巨摩山地北部東縁の活断 層, 活断層研究, 2, 33-42.

El-Ibiary, M. and Y. HagiWARA, 1987, Seismic and Gravity interpretations for the density structure of the Northern and Central region of Japan, J. Geodetic Soc. Japan, 33, 61-73.

藤森孝俊, 1991, 活断層からみたプルアパートベイズン としての諏訪盆地の形成, 地理評, 64, 665-696.

萩原幸男, 1990, 重力からみたフォッサマグナの構造と テクトニクス, 地学雑誌, 99, 72-79.

花井重次, 1934, 甲府盆地南縁の地形と其の成因につい て，大塚地理学会論文集，第二集，下，113-123.

平川一臣, 1982, 山梨県の地形に関する資料 (3)一曽根 丘陵のテクトニックバルジ, 山梨大学教育学部研究報 告, $33,93-101$.

平川一臣, 1992, 甲府盆地南縁, 曽根丘陵の撓曲崖, 月 刊地球, 号外 No. 5, 84-88.

平川一臣・神沢公男・浅川一郎，1989，巨摩山地北東 縁, 下円井の活断層露頭, 活断層研究, 6, 43-46.

池田安隆, 1992, 日本の逆断層: flake tectonics の可能 性について, 月刊地球, 5, 117-120.

池田安隆・米倉伸之, 1979, San Fernando 地震の断層 モデル:断層面のおれまがりとその地学的意義, 地震 $2,32,477-488$.

IKedA, Y. and N. Yonekura, 1986, Determination of late Quaternary rates of net slip on two major fault zones in central Japan, Bull. Dept. Geogr., Univ. Tokyo, 18, 49-63.

石橋克彦; 1983，甲府盆地周辺における 1854 年と 1923 年の地震被害のテクトニックな意義, 地震 2 , 36, 668-671.

金子史朗, 1972, 地形図説 2, 古今書院, 229 p. 活断層研究会, 1991，新編日本の活断層一分布図と資 料一, 東京大学出版会, $435 \mathrm{p}$.

衣笠善博, 1990 , 東北日本北米プレート再考一地形・地 質から一, 地学雑誌, 99, 13-17.

小林洋二, 1983, プレート“沈み込み”の始まり, 月刊 地球, 15, 510-514.

駒沢正夫・石原丈実・広島俊男, 1991, 日本列島の重力 図の作成之主な特徵, 月刊地球, 14, 166-173.

甲府盆地第四紀研究グループ，1969，甲府盆地の第四 系, 地団研尃報, 15, 254-258. 
河野芳輝, 1983, 中部日本北部の重力異常 (2)一地形, 地 震活動, 活断層, 構造線との比較一, 地震 $2,36,247-$ 253.

Mansinha, L. and D. E. Smylie, 1971, The displacement fields of inclined faults, Bull. Seism. Soc. Am., 61, 1433-1440.

松田時彦, 1989, 南部フォッサマグナ多重衝突説の吟 味, 月刊地球, 11, 522-525.

中村一明, 1983, 日本海東縁新生海溝の可能性, 地震研 彙報, 58, 711-722.

中村慶三郎, 1938, 甲府盆地周辺の丘陵に就て, 地質雑 誌, 45, 408-412.

日本の地質「中部地方 $\mathrm{I} 」$ 編集委員会, 1988, 日本の地質 4 中部地方 I, 共立出版, $332 \mathrm{p}$.

西宮克彦・石田 高, 1967, 「曾根丘陵の自然一特に地 下水理について一」, 山梨県地質図編集委員会, $37 \mathrm{p}$. 大塚弥之助, 1941, 山梨県鳳凰山・地蔵ヶ岳付近の地 質, 地震研彙報, 19, 115-143.

Rodgers, D. A. and W. D. Rizer, 1981, Deformation and secondary faulting near the leading edge of a thrust fault, McClay, K. R., and Price, N. J. eds., Thrust and napp tectonics. Geol. Soc. London, Spsc. Pub., No. 9, 65-77.

崎田竜二, 1961, 市/瀬台地, 「过村太郎先生古希記念 地理学論文集」, 古今書院, 100-106.
里村幹夫・安間秀明, 1986, 系魚川-静岡構造線南部地 域の重力異常, 静岡大学地球科学研究報告, 12,5574.

Satomura, M. 1989, Bouguer gravity anomalies in the south fossa maguna, Central Japan, Modern Geology, 14, 47-67.

澤 祥, 1981, 甲府盆地西縁・南縁の活断層, 地理 評, 54, 473-492.

Suzuki, T. 1991, Tephrochronological Study on Middle Pleistocene Volcanoes and Fluvial Terrace in Chubu-Kanto Area, Central Japan, 東京都立大学博 士学位請求論文.

Talwani. M., J. L. Worzel and M. Landisman, 1959, Rapid Gravity Computations for Two-Dimensional Bodies with Application to the Mendocino Submarine Fracture Zone, J. Geophys. Res., 64, 49-59.

田中啓爾, 1925, 甲府盆地 (1), 地理評, 1, 925-945.

海野芳聖, 1981MS, 甲府盆地の構造発達史之埋積過程, 東京大学修士論文.

渡辺満久, 1985 , 奥羽脊梁山脈之福島盆地の分化に関す る断層モデル, 地理評, 58, 1-18.

Yамамото, A., K. Nozaki, Y. Fukao, M. Furumoto, R. Shichi and T. EzAKA, 1982, Gravity survey in the central ranges, Honshu, Japan, J. Phys. Earth, 30, 201-243. 